\title{
Warak Ngendhog Commodification as a Kind of Creative Industry in Semarang City
}

\section{Komodifikasi Warak Ngendhog sebagai Bentuk Industri Kreatif di Kota Semarang}

\author{
Kharisma Ayu Febriana $^{1}$, Yuliyanto Budi Setiawan ${ }^{1}$, Firdaus Azwar Ersyad ${ }^{1}$ \\ ${ }^{1}$ Department of Communication, Faculty of Information and Communication \\ Technology, Universitas Semarang, Jl. Soekarno Hatta Tlogosari Semarang 50196, \\ Central Java, Indonesia \\ *Corresponding author, e-mail: kharisma@usm.ac.id
}

\begin{abstract}
Warak Ngendhog in Semarang City make it a cultural phenomenon. Some forms of commodification are used in the economic, political and cultural sectors. The purpose of this study is to find out the symptoms of the cultural phenomenon which has transformed into various forms. This research use qualitative analysis with descriptive approach. As for the results of this study, Warak Ngendhog which functions has transformed and changed, can be utilized in the cultural and tourism sectors as one of the cultural icons in the city of Semarang. Warak Ngendhog culture has contributed to the government of Semarang City with the emergence of various forms of its transformation into various forms of art and culture. In addition, this study is expected to give contribution in the field of cultural preservation in Semarang City.
\end{abstract}

Keywords: Warak Ngendhog, Commodification, Creative Industry.

\begin{abstract}
Abstrak
Warak Ngendhog di Kota Semarang menjadikannya sebagai sebuah fenomena budaya. Beberapa bentuk komodifikasi digunakan dalam sektor ekonomi, politik dan budaya. Untuk tujuan dari penelitian ini adalah untuk mengetahui gejala dari fenomena budaya yang telah berubah menjadi berbagai bentuk. Penelitian ini menggunakan analisis kualitatif dengan pendekatan deskriptif. Sedangkan untuk hasil penelitian ini, Warak Ngendhog yang fungsinya telah ditransformasi dan berubah, dapat dimanfaatkan di sektor budaya dan pariwisata sebagai salah satu ikon budaya di Kota Semarang. Budaya Warak Ngendhog telah memberikan kontribusi kepada Pemerintah Kota Semarang dengan munculnya berbagai bentuk transformasi menjadi berbagai bentuk seni dan budaya. Selain itu, penelitian ini juga diharapkan dapat memberikan kontribusi dalam bidang pelestarian budaya di Kota Semarang.
\end{abstract}

Kata Kunci: Warak Ngendhog, Komodifikasi, Industri Kreatif.

\section{Copyright () 2019 Universitas Semarang. All rights reserved.}

\section{Introduction}

The diversity of Indonesian culture is reflected in the part of local cultures that develop in the community. The diversity is formed not only internally, but also because of external influences that form a culture in a region. The development of local culture in each region certainly has significant role in increasing the spirit of nationalism, because every art of local culture contains social values of the local community. However, the issue of the swift flow of globalization has implications on the changing of the form and function of a culture while forming a new meaning of a culture.

Article History: Received October 01, 2018; Revised January 18, 2019; Accepted January 25, 2019; Published January 31, 2019 
Globalization gives very significant influence in an art and culture. Culture continues to develop dynamically and finally forms a new meaning of the culture. Benny H. Hoed explained that the term globalization had long been introduced in the State of Indonesia. Globalization exists due to the development of the world economy. In this case, the borders of the country economically are increasingly faded and disappeared altogether. Globalization is not something static in nature. This phenomenon is born from human behavior and the ideas born from various interactions among humans, society and state. In addition, globalization is not just an economic problem but also cultural phenomenon, namely the formation and the spread of 'world culture' in many countries. That means, a new culture is spreading and sweeping across the world (Hoed, 2011).

Indonesia as one of the developing countries in the world also experiences the impact of the rapid influence of globalization. As happened in the other countries, globalization has positive and negative influences on social order (Anawati, 2016). The influences of globalization on the national culture includes various sectors of life such as culture in the fields of politics, economics, ideology, social and others, quickly or slowly will influence the principles and identity of Indonesia's national culture.

Like the globalization that is influential in all parts of Indonesia, Semarang City as one of the major cities in Indonesia has experienced its impact. The implication is that there is a fairly rapid and transformative urban phenomenon such as in the downtown area, where there is an increase in the physical development of the city spatially, the utilization of city space and city activities such as in the increasingly massive trade and industry sectors (Wibowo, 2007). Industrial development in the cultural sector such as the implementation of events with the theme of tradition and culture is held lively and commodityically every year.

Commodification is an attempt to use culture that is produced by the elite class. This class ideologically has different life orientation than other classes, that is a glamorous lifestyle and always looking for status symbols as the part of cultural and social strategies (Djatiprambudi, 2010). Whereas according to Sumartono, commodification is the process of transforming goods and services along with their values into a commodity that has an exchange rate on the market. It feels strange, because generally media products are in the form of information and entertainment. While both types of products cannot be measured like movable goods in conventional economic measures. The tangibility aspects will be relatively different from the other goods and services (Sumartono, 2016).

The city of Semarang is currently trying to equalize its position with the other cities by realizing it as one of the cultured cities. Thus, the administration and the development of the city of Semarang are always based on all aspects of culture which consist of Creation, Feeling and Willing that have grown into the community wisdom such as the implementation of the values of religiousity, humanity, togetherness, brotherhood, order and other attitude of obedience in the cultural environment of the society, resulting in the development of character that emphasizes the refinement of mind and feelings, humanity, and the respect for human rights.

Local culture and traditional arts are increasingly the concern of the City Government. The preservation efforts are carried out to improve the cultural potential of Semarang people. Cultural performances are packaged lively and sustainably as a kind of attention of the city government to introduce and promote local culture which is the identity of the city of Semarang. In this case, the community becomes the potential supporting factor for advancing the regional culture. For this reason, the government requires all stakeholders to participate in succeeding the cultural performances organized 
by the city government. The impact of this increasingly massive cultural performance has implications on the social character of Semarang society as a kind of euphoria of urban society.

As for the development in the cultural sector, Semarang City Government plans various cultural performance events such as arts and culture festivals, sea alms gatherings, cultural gatherings, dugderan and other cultural performances. This is the strategic step of Semarang City Government as an evidence to be equalized as city of culture like other cities.

The government is currently in an effort to form branding by looking for symbols or emblem as the identity of the city. Many things are known by the public that Semarang City has a distinctive cultural variety. Viewed from Semarang's cultural buildings, it has Lawang Sewu, Gereja Blenduk, Sam Po Kong, and Tugu Muda. Viewed from typical food Semarang is identical with Bandeng Presto and Wingko babat. Viewed from traditional arts, Semarang has Semarang gambang dance, and the phenomenal event held annually, that is dogderan accompanied by the Warak festival.

From the searching process, Warak is the one that now becomes the concern of the City Government. Warak Ngendhog is the only cultural symbol capable of representing the condition of Semarang city people. Djawahir explained that Warak Ngendhog is a mythological animal which is described as the unifying symbol of the three major ethnic groups in Semarang. Towards the holy month of Ramadan this imaginary animal becomes the mascot in the Dugderan festival. Warak Ngendhog is originated from a cultural ritual carried out by the residents of Semarang to welcome Ramadan called Dugderan. Thus, the people believes that the city of Semarang was built with the spirit of pluralism involving all components (Javanese, Chinese, Arabic) and by that belief they create momentum, rites, and other activities that are characterized by multicultural, multi-ethnic or cross-cultural ones, one of which is the dugderan festival by involving Warak Ngendhog as its icon (Muhamad, 2012).

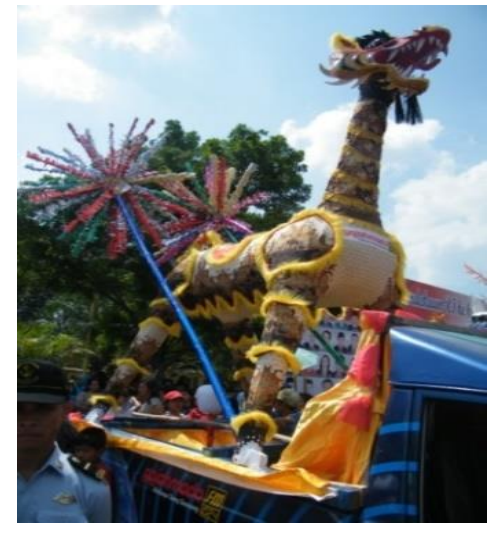

Figure 1. Warak Ngendhog

(Source: Researcher, 2017)

The Warak Ngendhog Statue is an art work for attracting attention and symbolic media in the ritual tradition of dugderan (a ritual activity that begins with a crowd or night market for a month full of people selling food, drinks and children's toys). Some elements of the form of Warak such as Head, Body and Legs are the symbols of acculturation of several ethnic cultures in the city of Semarang. Warak is made in the form of an imaginary animal which is a combination and stylation of several parts of living things. If it is observed partially there is a dragon-shaped head, as a distortion and stylation of a 
combination of snake, lion and deer. There is also one who said that it is head-kiln, a sacred animal in China mainland with a shape resembling a giraffe.

The statue body of Warak Ngendhog shows the body of a mammal animal like a cow or goat, because when it is viewed from the large size it is like a cow while for the medium size is the goat. The tail resembles the tail of a lion or cow that looks up. The combination of the animal parts creates an imaginary animal, imaginative, or out of the ordinary minds of the people, the imaginative power is added with varied colors on the fur, looks more unique with the egg or 'endhog' between the two behind legs of the statue, so that it is known as Warak Ngendhog. In the procession of the pageant, Warak Ngendhog was created as a unique and creative form that was expected to attract the attention of the dugderan ritual visitors.

The current community understands how Warak Ngendhog now becomes a cultural symbol that must be preserved to form a spirit of pluralism in the city of Semarang. In addition to preserve the cultural values of the city of Semarang, this carnival commoditatively is expected to be able to attract the foreign tourists to visit the city of Semarang. This imaginary animal which is a kind of cultural ritual is now starting to transform into an urban art form that is becoming popular in many communities, especially the citizens of Semarang. For example is the form of Warak Ngendhog as a cultural symbol that is innovated as shown below:
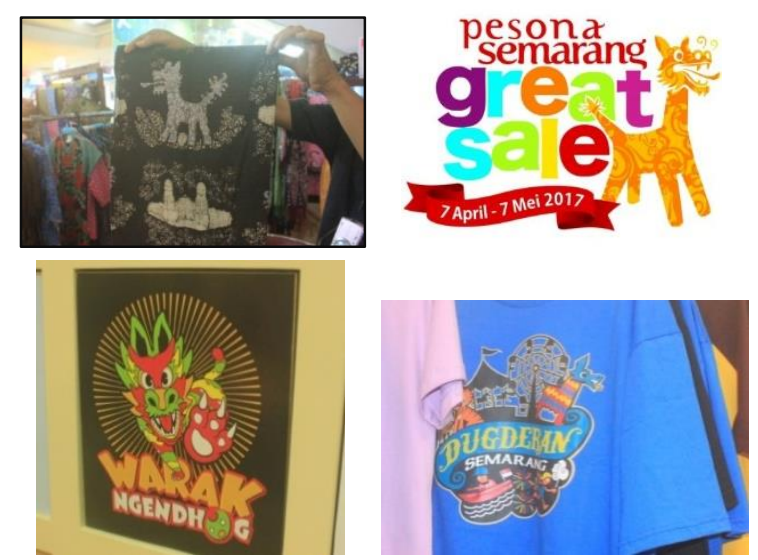

Figure 2. The Innovation of Warak Ngendhog

(Source: Researcher, 2017)

By modifying the shape of Warak Ngendhog above, then Warak Ngedhog shape is shifting in the mean time switching functions in terms of showing an urban phenomenon. This is because the process of cultural modification is one of the alternatives taken by diverting the choices in the creative economy sector, namely creativity and intellectual ability based economy. This phenomenon is quite interesting because Warak Ngendhog is a 'borrowed' art to develop the Creative Industry sector in the city of Semarang to increase the regional economic income.

The term creative industry is another term for the cultural industry. The term was first used in the early 1990s in Australia, but it was developed rapidly by the British government in the late 1990s. The British government specifically established the Unit and Responsible for Creative Industries under the Department of Culture, Media and Sports. There are many definitions of creative industries, one of the many cited definitions is the industry that has authenticity in individual creativity, skills and talents that have the potential to generate income and job creation through intellectual property exploitation. 
The cultural phenomenon of Warak Ngendhog is now becoming more interesting because there are not many people talking about the animal in the dimensions of cultural industry. The scarcity of discussion about the culture of Warak Ngedhog and its relationship with industry is that because in essence the culture is born not within the framework of industry, but the culture of Warak Ngendhog is born within the framework of ideology. As stated by Djawahir Mohamad that the shape of warak and the characteristics of Semarang people are related. The linkage is based on the straight angles of the traditional physical shape of warak as a characteristic that has significance with the cultural symbols, attitudes and behaviors of 'Semarang people'. Warak was originally a characteristic representation of Semarang City residents but now Warak in the context of cultural industry represents a commodity.

However, market ideology has changed the new function of Warak Ngendhog art itself, although it is always associated with the efforts to preserve regional culture, which is not separated by the consideration for gaining benefit or profit. As stated by Sapardi Djoko Damono that the impulse to exploit culture has changed the same message in various vehicles, or has given birth to new vehicles for a message that is the same but 'boarded' by other types of messages (Damono, 2012). The message in the form of a new ideology changes the meaning of the ideology from Warak Ngendhog community art which is shifting into a commodity object of the cultural industry in the city of Semarang.

The shape of Warak Ngendhog cultural industry in this matter is quite diverse and varied. In addition, the beneficiary of Warak Ngendhog culture which is functioned as a commodity makes the historical and philosophical meanings biased and degraded. Thus, based on the background described above, this study will analyze the practice of commodification of Warak Ngendhog culture in the city of Semarang more deeply.

The focus of this study is to answer and to discuss some important indicators related to the practices of Warak Ngendhog commodification and their implications on the development of urban society. Specifically, some of the problems raised are: 1). How is the process of the commodification of Warak Ngendhog culture in the city of Semarang? 2). What are the implications of the commodified Warak Ngendhog Culture? 3). How is Warak Ngendhog Image shaped according to its new vehicle as a commodity medium in Semarang City?

\section{Methodology}

The method used in this research is descriptive qualitative research method. The characteristics of qualitative research itself is the research aimed at interpreting the social phenomena and cultural symptoms that occur in Semarang city. In this study the researchers examined the practice of cultural commodification in this matter is Warak Ngendhog, which in this decade gives sufficient significant changes. These changes include aspects of function, shape and meaning that are constructed along with the changing patterns of urban community activities in Semarang. From these symptoms, the researcher is the key instrument, the data collection technique in this study is conducted in triangulation, data analysis is inductive, and the results of qualitative research emphasize the meaning rather than generalization.

This research was conducted in Samarang city, among others, various places that have relevance related to the research conducted. The locations of the research include: Semarang City Hall as the venue for festivals and carnival of Warak Ngendhog, Semarang City Culture and Tourism Office as the stakeholder institution in the field of cultural performances in Semarang City, Semarang Kauman Mosque, Semarang creative industry 
center such as Matahari shopping center, ADA supermarket, Gojeg (annoying joke) and Semarang Batik Village.

According to Lofland, the main data source in qualitative research are words and actions, the rest are additional data such as documents and others. Data are the information obtained from a study and the data will be needed to analyze the problems and the difficulties faced later. Then, the data are used to find alternative solutions that are deemed appropriate and the most effective (Sutopo, 2006). The data collected in this study are qualitative data which include:

a. The data concerning the description of Warak Ngendok culture reviewed from the historical, philosophical and current shapes and the data relevant to the process of transformation and commodification of Warak Ngendhog culture.

b. Other data related to the research conducted.

In order to collect data and information, then the writers used the following data:

a. Primary Data

Primary data are the main data directly obtained from data sources from the researchers to achieve the research objectives. In this case, the primary data sources are the creativity doers of the creative industry, the Head of Semarang City Culture and Tourism Office, Semarang cultural figures, academics and cultural participants (Semarang City residents).

b. Secondary Data

The secondary data are the data obtained by collecting and selecting the data in the form of books, newspapers, magazines, scientific journals and literature relevant to the problems examined in this study.

The research relevant to the subject matter of this study is the work of Supramono which analyzes the meaning of warak culture by using the study of semiotics. In his study Supramono explained that the meaning of warak ngendhog is related to analyzing the relationship of visual structure and based on the original denominator, its visual form, and the procedures in presenting dugderan (Supramono, 2007)

Qualitative research is basically an investigation process similar to detective work. From an investigation, the main data and the additional data will be collected. The main data sources in qualitative research are words and actions, while written data, photographs and statistics are the additional data as well as the supporting data.

In the process of collecting data, as an information data, the researchers must be careful. The researchers neeed to consider several things, including the accuracy of the data in accordance with the problem being studied, the data source must have fairly high level of trust, the data in the document must not have distortion in either the text or visual and audio display. In addition, permission has been obtained from the owner of the document or copyright if needed or at least cited in the manner of the custom of citation in accordance with academic ethics in general (Rohidi, 2011).

In the data collection stage, the methods and techniques used are: literature study, observation, interviews, as well as reviewing documents and archives. The methods and techniques used in this study include:

a. Library or Literature Study

Library study is an effort to obtain data and information related to the object of research by studying various literature, either books, public and internal magazines, journals, scientific papers and so on. 


\section{b. Observation}

Observation or surveillance is the daily activities of humans by using the five senses where the eyes are as the main aid tools besides the other five senses, either ears, smell, mouth and skin. Therefore, observation is the ability of a person to use the observer through the five senses. Thus the technique of collecting data with observation means the process of collecting data used to collect research data is through observation and sensing. c. Interview

Interviews are methods of retrieving data by asking something to someone who becomes an informant or respondent. It is done by having conversation face to face. Interviews are used to get data directly about the object of the research. The interview is conducted by performing questions and answers directly to the respondents.

d. Documentary Method

The documentary method is one of the methods of data collection used in social and cultural research methodologies. In essence this method is used to trace historical data (Bungin, 2012). Thus in analyzing a historical research object, the documentary material makes a significant contribution. In this case, in the study of the cultural industry of Warak Ngendhog, the documentary method was conducted to find out the historical discourse built from several sources.

The main nature of these data are that there is unlimited space and time so that it gives an opportunity for the researchers to know the things that have happened in the past. Data sets in the written form are called documents, in a broad sense including monuments, artifacts, photos, tapes, CDs, flashdisks and so on.

Document material is explicitly different from literature, literature is material that is published, either regularly and periodically, while documentary is the information that is stored or documented as documentary material. Burhan Bungin explained in detail the various documentary materials as follows: autobiography; personal letters, memorial books or diaries; scrapbook; government and private documents; romance or folk tales; data on the server, either VCD, DVD or flashdisk; the data stored on the website and others. Thus the documents regarding Warak Ngendhog are obtained through personal documents which are carried out through the observation process and then perpetuated through writing and digital media, namely DSLR (Digital Single Lense Reflex) Camera.

\section{Result and Discussion}

In this study, we can see how the commodification, standardization and massification in the cultural industry of Warak Ngendhog occurred in Semarang City. The commodification meant in this discussion can be described as the way capitalism achieves the goal of accumulating capital or realizing the values through transformation from the function value into the exchange value. Warak Ngendhog has become a multifunctional culture, besides being used as education and entertainment media, Warak Ngendhog has now begun to contribute to help the capitalists gather the capital and economic benefits.

Basically, the principle of capitalism dynamic is the process of production, distribution and consumption, in which the main goal of the process is not only the value of the use/function from the production process to consumption, but also through exchange rates that occur in market process which makes the profit of the capital accumulation efforts maximal. Thus, commodification is the process of transforming the use value into an exchange rate. 
Because the mass has been formed, the industry feels it is important to make certain standards in the Cultural industry, in this case is the cultural industry of Warak Ngendhog. In addition, the bureaucrats or the government make policies in an effort to popularize and provide creativity space for the people who use Warak Ngendhog as traditional arts that can be commercialized for economic and industrial interests.

The culture that has been commodified in a political circle will have an effect on all matters such as the impact on the social and economic aspects of Semarang City. Thus the mass that has been formed is not only generated from the result of a culture massification, but it also has an impact on the market. When the community will make a Warak model that has become a public convention, the majority thinks that this Warak with Dragon head has implication on the decoded results that have been made by the public. Thus, the results of a standardizarion has been formed and the impact can add value to the products produced by the community.

The development of arts and culture that has been carried out by the community and as the contribution of the government/ranks of bureaucrats turns out to be an advantage for the owners of the industry, because they can get an interesting material for sale. The commodification in this study refers to the effort to make Warak Ngendhog as the source of income for the supporting community. In addition, commodification was also carried out as an effort to preserve Warak Ngendhog in the midst of global culture that begins to influence the people of Semarang City. Thus, in this sub-chapter, we will explain how the process of commodification, standardization and massification of Warak Ngendhog shape occurs. Meanwhile, the following is the visual of Warak Ngendhog before being commodified.

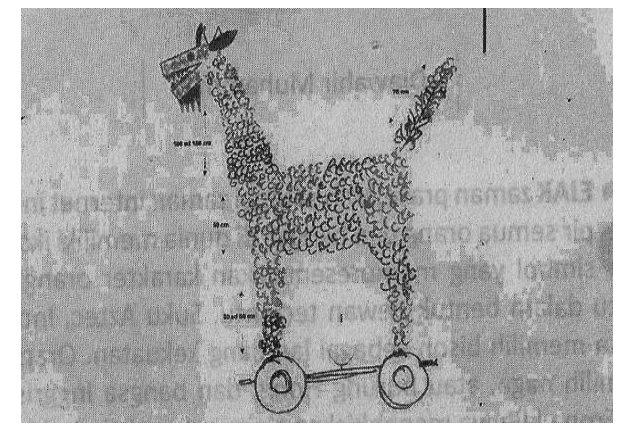

Figure 3. Warak Ngendhog before being Commodified

(Source: Researcher, 2017)

Commodification is a kind of transformation of a relationship, which is initially free from things that are trafficked, into commercial relationships. If we review the results of the data which have been found that the tradition of Warak Ngendhog was originally only as an educational medium to warn children to practice fasting. But after the emergence of the dugderan market, the efforts of commodification, standardization and massification of Warak Ngendhog began to emerge at that time which more or less happened in 1881. Thus, the efforts of Warak Ngendhog to become a cultural industry had taken place since the people were trading their own culture.

In the last decade, there have been so many images of Warak Ngendhog that were spread by various media and vehicles so that they have been seen as the result of public conventions. The media is considered to have the potential to play the public understanding of a cultural symbol, in this matter is Warak Ngendhog. The media is considered to perpetuate unrealistic ideals. The many artists, the creators of art who 
created the symbol of Warak Ngendhog in various events became a very valid conception that Warak Ngendhog is now increasingly popular.

In the process of its reproduction, Warak Ngendhog Shape began to pay attention to market tastes. Initially this was done without leaving the basic aesthetic values in the shape and philosophical values contained therein. Matters related to the production process of Warak Ngendhog shape were identified in 2 things. First, Warak Ngendhog in a series of commodification in creative industries such as the use of Warak Ngendhog in the form of T-shirts, Lights, Batik, Bags and so on. Warak Ngendhog in the series of commodification in large events organized by the government or private parties such as the use of logos in Semargres (Semarang Great Sale) event, Ayo Wisata to Semarang, Pilwalkot, Semarang Night Carnival, Robotic Festival, Persenasma and Warak Boat Festival, because affixing the logo is a part of cultural existence.

If we concern on the commodification programs of Warak Ngendhog shape, there is implicitly the legitimacy of the regional government authority, while the community sometimes doesn't understand it well. On the contrary, the community is shaped to feel happy and obedient to the programs that were expressed through cultural symbols representing the public, the ultimate goal of which is to obey the state, in this case the regional government of Semarang city. The political efforts of the regional government to obtain the amount of mass support become more and more through the cultural channels. Besides that, the commodification that has been carried out by the government indirectly is as a kind of support from the existence of one of the benefited ethnicities.

Furthermore, it will be reviewed during the standardization process. Standardization is an effort to homogenize products to make it easier for the industries to produce them. This means a process to generalize mass cultural products to industrial tastes. The process of standardization is in the reproduction of Warak Ngendhog shape. If it is viewed from the traditional discourse, the standardization in the New Order era according to Papara Lilis and Bintang Anggoro that the standardization of Warak Ngendhog shape was a small, straight, rigid shape and functioned as children's toy. It was given wheels under its feett that aims to be able to be pulled by the children, remembering that at that time Warak Ngendhog was functioned as children's toy.

For the last decade when science and knowledge is growing more rapidly, it has implications for the increasingly imaginative Warak Ngendhog shape in the form of digital imaging. Changes that occur at this time can be seen that standardization finally happened because of the demands for the City government policy. The structural patterns of Conventional Warak shape and the one which has been in the form of digital somulation result (digital imaging) in the form of logos have almost had the similarity, just like in the form of visual transformation such as Warak Ngendhog below:

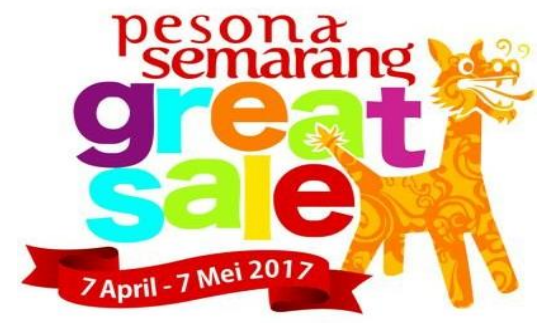

Figure 4. Visual Transformation of Warak Ngendhog

(Source: Researcher, 2017) 
The figure above has the same head structure which is indicated to resemble a dragon's head. This shape of warak in the iconic design concept continues to develop in accordance with the events held by the Semarang city government. The shape of the warak head which originally had various types of animals such as the combination of snakes, lions and deer now begins to be converted into the head of a dragon.

\section{Conclusion}

After performing the process of studying the commodification of Warak Ngendhog as a form of creative industry in Semarang, there are field findings found in the object of research and then triangulating in the form of synthesis with theories and the related reference materials. The conclusions that can be drawn among others are: First, Warak Ngendhog is a cultural tradition which existence is still intact as a representation of the people of Semarang city until now. Second, the development of Warak Ngendhog began to be varied and innovative, coming from a series of annual events held by the Semarang city government. Warak 'is borrowed' as the logos of 'Pilwalkot', 'Semargres', Semarang Night Carnaval and others. Until all have an effect on the changing of cultural values which initially are very attached to philosophical and historical meanings. Warak has now turned into a political symbol, economic symbol and capitalist symbols.

If it is viewed from the initial shape of its appearance, Warak Ngendhog is not intended as an acculturation symbol of Chinese, Javanese and Arabic cultures. It is just a fictional animal produced by the clerical elder which is intended as a means of planting Islamic values to the children in the form of toys. Through it, the children are inspired to be excited and happy to welcome the coming of the holy month of Ramadan. As a cultural tradition, when it has become the property and expression of a community group, it will experience development and even changes in both the form and meaning. In addition, supported by Semarang City as a coastal area, it is relatively opened and influenced by the dynamics life of the outside community and its culture that are multiethnic and multiculture. Finally/Third, Warak Ngendhog is perceived or interpreted by the community as a symbol of cultural acculturation because of the desires or needs from all citizens of Semarang community consisting of Javanese, Arabic and Chinese ethnic groups to form an integrated culture.

\section{Acknowledgment}

The Writers Team thanks to the Ministry of Research, Technology and Higher Education of the Republic of Indonesia (Kemenristekdikti) that has given the fund for the Writers Team research scheme (Beginner Lecturer Research ('Penelitian Dosen Pemula')) with the title 'Warak Ngendhog Commodification as a Kind of Creative Industry in Semarang City'. This research hopefully can be useful and give additional scientific knowledge in the field of communication in general and cultural communication in particular.

\section{References}

Anawati, Y. S. (2016). Kajian Fenomena Urbanisme Pada Masyarakat Kota Ungaran. Semarang.

Bungin, B. (2012). Penelitian Kualitatif Komunikasi,Ekonomi, Kebijakan Publik, dan Ilmu Sosial Lainnya. Jaka: Kencana Prenada Media Group.

Damono, S. D. (2012). Alih Wahana. Jakarta: Editum.

Djatiprambudi, D. (2010). Komodifikasi Seni Rupa Kontemporer. Jurnal Panggung, 50. 
Hoed, B. H. (2011). Semiotika dan Dinamika Budaya. Depok: Komunitas Bambu.

Muhamad, D. (2012). Membela Semarang. Semarang: Pustaka Semarang.

Rohidi, T. R. (2011). Metodologi Penelitian Seni. Semarang: Cipta Prima Nusantara.

Sumartono. (2016). Komodifikasi Media dan Budaya Kohe. Jurnal The Messenger, 8(2), 43-51. http://dx.doi.org/10.26623/themessenger.v8i2.342

Supramono. (2007). Makna warak Ngendhog dalam tradisi ritual dogderan. Semarang.

Sutopo, H. (2006). Metodologi penelitian Kualitatif (Dasar Teori dan terapannya dalam Penelitian). Surakarta: UNS Press.

Wibowo, F. (2007). Kebudayaan Menggugat. Yogyakarta: Pinus Book Publisher. 